\title{
Indoor Air Quality: A Focus on the European Legislation and State-of-the-Art Research in Italy
}

\author{
Gaetano Settimo $^{1}\left(\mathbb{D}\right.$, Maurizio Manigrasso ${ }^{2}$ and Pasquale Avino ${ }^{3, *}$ \\ 1 Italian Institute of Health, viale Regina Elena 299, I-00185 Rome, Italy; gaetano.settimo@iss.it \\ 2 Department of Technological Innovations, INAIL, via Roberto Ferruzzi 38, I-00143 Rome, Italy; \\ m.manigrasso@inail.it \\ 3 Department of Agriculture, Environmental and Food Sciences, University of Molise, via F. De Sanctis, \\ I-86100 Campobasso, Italy \\ * Correspondence: avino@unimol.it; Tel.: +39-087-440-4631
}

Received: 1 March 2020; Accepted: 8 April 2020; Published: 10 April 2020

\begin{abstract}
The World Health Organization (WHO) has always stressed the importance of indoor air quality (IAQ) and the potential danger of pollutants emitted from indoor sources; thus, it has become one of the main determinants for health. In recent years, reference documents and guidelines have been produced on many pollutants in order to: i) decrease their impact on human health (as well as the number of pollutants present in indoor environments), and ii) regulate the relevant levels of chemicals that can be emitted from the various materials. The aim of this paper is to discuss and compare the different legislations present in the European Union (EU). Furthermore, a focus of this paper will be dedicated at Italian legislation, where there is currently no specific reference to IAQ. Although initiatives in the pre-regulatory sector have multiplied, a comprehensive and integrated policy on the issue is lacking. Pending framework law for indoor air quality, which takes into account WHO indications, the National Study Group (GdS) on Indoor Air Pollution by the Italian Institute of Health (IIS) is committed to providing shared technical-scientific documents in order to allow actions harmonized at a national level. An outlook of the main Italian papers published during these last five years will be reported and discussed.
\end{abstract}

Keywords: indoor air quality; legislation; Europe; focus; residential; pollutants; TLV; health; workers; school

\section{Introduction}

Indoor air quality (IAQ) has been a well-known problem since the late 1970s. Its significant impact on human health has been addressed several times by the World Health Organization (WHO) in various documents and meetings, and has been carried out at various levels [1-3]. Further, economic studies and researches have highlighted the great importance that IAQ now has in all environments, e.g., houses, schools, banks, post offices, offices, hospitals, and public transport, just to name a few [4]. IAQ also has strong repercussions in the competitiveness of an organization, considering the increase in difficulty in carrying out its job in the best way, its performance, and the social and economic competitiveness between countries, due to the influence on the attention, degree, and number of days lost [5].

Scientific literature contains large documentation in terms of articles, conference papers, reviews, books, editorials, letters, and public articles on chemical contaminants in indoor environments. A search on the Scopus literature database, using the keyword "indoor air quality", led to a total of 7287 publications between 2000 and 2020 in the European Union (EU) (search executed on 19 January 2020), including Norway, Switzerland, and Turkey. According to this search, Italy and the 
United Kingdom (UK) are major contributors to this total amount of European publications, $12.3 \%$ and $10.4 \%$ of the total, respectively, followed by France and Germany with $9.5 \%$ and $9.1 \%$. Figure 1 shows the relative percentage contribution of each Member State of the European Union (EU) including Norway, Switzerland, Turkey, as well as United Kingdom, which is expected to leave the EU on 31 January 2021. The United Kingdom, Italy, France, and Germany contribute more than $41 \%$ of the total amount of publications in the European IAQ field.

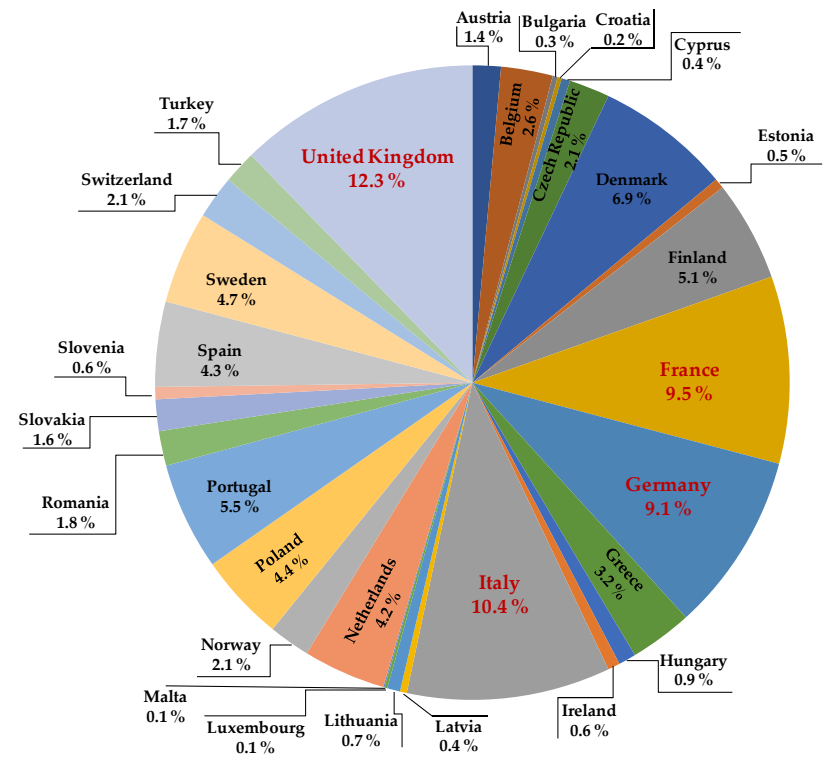

Figure 1. Percentage of country contributions to the total amount of publications on indoor air quality (IAQ) in Europe from 2000 to 2020. (Source: Scopus, search: 19 January 2020); includes Norway, Switzerland, Turkey, and the UK, which is to be expected to leave UE on 31 January 2021.

This continuous and growing attention on IAQ has evidenced, over time, the need for a profound cultural change, according to WHO indications, in order to develop organic health prevention and promotion actions, and cope with the complexity of such an issue.

Noteworthy, at the European Community level, the resolution of 13 March 2019, defends clean air for everyone and highlights that people spend almost $90 \%$ of their time in indoors [6]. In these environments, the air can be significantly more polluted compared to outside [7] and, therefore, considered mandatory to issue indoor air quality certificates for both new and old buildings. From this perspective, it urges member states to adopt and implement measures to combat air pollution at the source.

There are specific cases, such as schools, healthcare, or office environments, where the permanence of workers (e.g., medical, administrative, teaching, and non-teaching staff) is supposed to last for a relatively long period, and where "users", as well, are present (e.g., patients, students, vulnerable and/or fragile subpopulation, some of which with physical and psychological disabilities, etc.). In these situations, it is essential to consider the very close relationships between the various work activities and the quality of the building structure, finish, furnishings, and the degree of crowding of such environments. This includes the presence of technological systems or interventions for energy purposes only, without forgetting the ventilation needs of the environment for aspects related to health, performance, and staff and student performance [8].

The combination of these actions is fundamental for developing and implementing plans for the protection and promotion of health safety for citizens and workers [9]. This represents the priority and the common objectives of both national and European prevention plans (National Prevention Plans (NPPs) and programs from the United Nations (UN) Sustainability Development Agenda). 
Nonetheless, several European countries have had to overcome the absence of specific legislation, or legislative acts already developed, due to generic definitions of the characteristics of air quality. For instance, in closed workplaces, such as closed offices where employees have individual working areas that are distinctly divided - either by walls, cubicles, or panels-it is necessary to ensure that workers have healthy air in sufficient quantity, which is also obtained with ventilation systems [10]. It is necessary for updated laws and regulations to be adopted to improve the indoor air quality.

Another fundamental requirement for correct understanding of the air quality pollution phenomena indoors is the availability of reliable (and systematically collected) information, according to well-established protocols, on the quality, quantity, and origin of the pollutants. In this regard, particular attention should be addressed to the activities of the European Committee for Standardization (CEN) and the International Organization for Standardization (ISO), which provide a series of specific indications on the operating procedures with which to carry out the checks.

In recent years, several international organizations, e.g., the European Collaborative Action (ECA), the World Health Organization (WHO), and the International Agency for Research on Cancer (IARC) have produced reference documents, guidelines, agreements, and protocols. For example, the Parma declaration, the Children's Environment and Health Action Plan for Europe CEHAPE), European Union (EU) regulations (e.g., regulation 305/2011, which lays down harmonized conditions for the marketing of construction products); documents, and rules for characterization and determination on many pollutants (e.g., European Standards (EN) ISO 16000-Indoor air quality, European technical specification (CEN/TS) 16516: construction products-determination of emission into indoor air). The purpose of this documentation is to tend to the decrease in the number of pollutants present in indoor environments and to regulate the levels of chemicals that can be emitted from different materials, in order to contain the negative impacts on IAQ. In particular, the activities carried out by the European Committee for Standardization (CEN) and the International Organization for Standardization (ISO) represent important references, because harmonized methods of detection allow for better comparison between the different indoor air quality data produced at the European level. Such methods should be implemented by laboratories that carry out environmental surveys.

Within this context, the aim of this paper is to summarize the entire legislation on IAQ present in the EU (the UK included), in February 2020, along with reference values, guide values, and unitary risks for many kinds of indoor air pollutants present. Particularly, the foundations of the different legislations will be compared for evidencing the main characteristics of each one, and the levels of the main pollutants will be presented and discussed. The focus is to highlight the strengths and weaknesses to deal with this important topic. According to the authors' knowledge, this is the first critical revision of the European legislation. Further, a section will be dedicated to the state-of-the-art research in Italy, from a legislative and scientific point of view. Although there have been many scientific papers and studies performed on IAQ, and a methodic and analytical review of the papers published in the last five years concerning the indoor field will be documented, it will be highlighted that, in Italy, the main problem is the lack of reference standards for residential indoor air quality.

\section{The Main European Legislation on Indoor Air Quality}

The WHO has developed guidelines for IAQ, relating to a certain number of pollutants, present indoor, for which scientific knowledge relating to human health effects were considered robust enough. The substances considered are benzene $\left(\mathrm{C}_{6} \mathrm{H}_{6}, \mathrm{CAS}\right.$ number $\left.71-43-2\right)$, nitrogen dioxide $\left(\mathrm{NO}_{2}\right.$, 10102-44-0), polycyclic aromatic hydrocarbons (especially benzo[a]pyrene $\mathrm{BaP}, \mathrm{C}_{20} \mathrm{H}_{12}$, 50-32-8) (PAHs), naphthalene $\left(\mathrm{C}_{10} \mathrm{H}_{8}, 91-20-3\right)$, carbon monoxide $(\mathrm{CO}, 630-08-0)$, radon, trichlorethylene $\left(\mathrm{C}_{2} \mathrm{HCl}_{3}\right.$, 79-01-6), and tetrachloroethylene $\left(\mathrm{C}_{2} \mathrm{Cl}_{4}, 127-18-4\right)$. For carcinogenic pollutants (such as benzene, $\mathrm{BaP}$, trichloroethylene), a unitary risk (UR) is defined for the general population associated with their presence in the air. Alongside these guidelines, mention should be made of those relating to the risks associated with the presence of humidity and biological agents. Furthermore, for the purpose of risk assessment, it is of particular importance to consider not only the guide value or reference 
parameter, but also other fundamental elements, such as the vulnerability of the population and the exposure conditions.

There is no specific reference directive on IAQ in European legislation, although pre-legislative initiatives have multiplied over the years. For example, indoor air quality and its impact on human activities within the European Collaborative Action (ECA), e.g., Urban Air, Indoor Environment, and Human Exposure, as well as funded studies, EN standards, etc.); however, to date, there is still no integrated policy on indoor air quality in all of those indoor places.

Some EU Member States, such as France, Portugal, Finland, Austria, Belgium, Germany, the Netherlands, and Lithuania, have started, through a series of actions, to adopt specific guide values, reference values, and action values for IAQ - in some cases enforced in the legislative acts of these countries. These actions can be summarized as follows:

- definition and imposition of reference concentration values on selected pollutants, in line with those developed by the WHO for some time;

- $\quad$ national plans on IAQ;

- drafting of legislative acts for indoor environments;

- $\quad$ setting up and planning mandatory indoor air monitoring activities;

- training and information programs dedicated to technical offices, managers, and staff on IAQ issues;

- protocols and guides for self-diagnostic activities based on scientific knowledge and practical experience on indoor air quality.

One particular aspect is to give indications for the IAQ evaluation at workplaces other than industrial ones. Currently, in order to evaluate the IAQ in environments where work is carried out (e.g., in offices, schools, hospitals, banks, post offices, etc.), the occupational exposure limit values (OELs) present in the regulations, or the threshold limit values (TLVs) of the American Conference of Governmental Industrial Hygienists (ACGIH), or the Scientific Committee For Occupational Exposure Limits (SCOEL-RAC) are used-albeit reduced by $1 / 10$ or $1 / 100$. This approach is overcome, as indicated, by specific documents elaborated by different national and European working groups on the indoor topic [11-14]. Such recommendations, as given by the WHO in the early 1980s in the document "Indoor air pollutants exposure and health effects" [15], reported that it was incorrect to use the industrial occupational exposure limit values for non-industrial indoor environments, and that for such environments, it was necessary to develop specific references. It should be remembered that these values represent the parameters to which references must be made for an assessment of the inhalation risk of workers and the population. They are not the only ones, because specific exposure and vulnerability conditions are fundamental elements to be considered for a correct risk assessment. In the document "Opinion on risk assessment on indoor air quality" [16], the Scientific Committee on Health and Environmental Risks (SCHER) of the European Commission recommends that risk assessment should always be focused on the most vulnerable groups, represented by children, pregnant women, elderly people (over 65), people suffering from asthma, and other respiratory and cardiovascular diseases, following a case-by-case approach. In fact, for groups of particularly sensitive and vulnerable individuals, who are potentially being exposed to the risk factors under consideration, the problem of the simultaneous presence of multiple risk factors may require the need to carry out specific in-depth assessments, which must be based on adequate knowledge of the context. In fact, it should be remembered that the reference values for confined spaces are more severe than the corresponding values in industrial environments (TLVs) whose hygienic-sanitary references are based on a working life of $8 \mathrm{~h}$ a day, 5 days a week, for a maximum period of 40 years, and are aimed at protecting workers against occupational diseases.

In this context, the efforts carried out by bodies such as ISO and CEN, which have long been involved in the development of the specific standard "EN ISO 16000: Indoor air" [17], which describes the procedures for performing sampling activities and analyzes the main pollutants indoors, should not be forgotten. The adoption of these rules constitutes a significant improvement compared to 
what has been achieved so far in the study and control activities. The standardization of the methods also increases the possibility of a correct comparison between the different indoor air quality data produced at the European level [11]. The advantage is, also, in terms of the possibility of the correct comparison between the various IAQ data produced at the European level, underlining the need for timely application of the rules. This is particular so for the sampling phase (e.g., choice of the sampling point and height, distance from walls, preliminary activities, etc.), which represents the beginning of the control procedure and, therefore, conditions the final result. Table 1 shows the 40 parts of the ISO 16000 standard [17].

Table 1. List of International Organization for Standardization (ISO) 16000 series for IAQ. EN = European Standard.

\begin{tabular}{|c|c|}
\hline & EN ISO 16000 «Indoor Air» \\
\hline Part 1 & General aspects of sampling strategy \\
\hline Part 2 & Sampling strategy for formaldehyde \\
\hline Part 3 & Determination of formaldehyde and other carbonyl compounds-active sampling method \\
\hline Part 4 & Determination of formaldehyde-diffusive sampling method \\
\hline Part 5 & Sampling strategy for volatile organic compounds (VOCs) \\
\hline Part 6 & $\begin{array}{l}\text { Indoor air Determination of volatile organic compounds in indoor and test chamber air by active } \\
\text { sampling on Tenax TA sorbent, thermal desorption, and gas chromatography using MS or } \\
\text { MS-flame ionization detector (FID) }\end{array}$ \\
\hline Part 7 & Sampling strategy for determination of airborne asbestos fiber concentrations \\
\hline Part 8 & Determination of local mean ages of air in buildings for characterizing ventilation conditions \\
\hline Part 9 & $\begin{array}{l}\text { Determination of the emission of volatile organic compounds from building products and } \\
\text { furnishing-emission test chamber method }\end{array}$ \\
\hline Part 10 & $\begin{array}{l}\text { Determination of the emission of volatile organic compounds from building products and } \\
\text { furnishing-emission test cell method }\end{array}$ \\
\hline Part 11 & $\begin{array}{l}\text { Determination of the emission of volatile organic compounds from building products and } \\
\text { furnishing-sampling, storage of samples, and preparation of test specimens }\end{array}$ \\
\hline Part 12 & $\begin{array}{l}\text { Sampling strategy for polychlorinated biphenyls (PCBs), polychlorinated dibenzo-p-dioxins } \\
\text { (PCDDs), polychlorinated dibenzofurans (PCDFs), and polycyclic aromatic } \\
\text { hydrocarbons (PAHs) }\end{array}$ \\
\hline Part 13 & $\begin{array}{l}\text { Determination of total (gas and particle-phase) polychlorinated dioxin-like biphenyls and } \\
\text { polychlorinated dibenzo-p-dioxins/dibenzofurans-collection on sorbent-backed filters with } \\
\text { high resolution gas chromatographic/mass spectrometric analysis }\end{array}$ \\
\hline Part 14 & $\begin{array}{l}\text { Determination of total (gas and particle-phase) polychlorinated dioxin-like biphenyls (PCBs) } \\
\text { and polychlorinated dibenzo-p-dioxins/dibenzofurans (PCDDs/PCDFs)-extraction, clean up, } \\
\text { and analysis by high-resolutions gas chromatographic and mass spectrometric analysis) }\end{array}$ \\
\hline Part 15 & Sampling strategy for nitrogen dioxide $\left(\mathrm{NO}_{2}\right)$ \\
\hline Part 16 & Detection and enumeration of molds-sampling of molds by filtration \\
\hline Part 17 & Detection and enumeration of molds-culture-based method \\
\hline Part 18 & Detection and enumeration of molds-sampling by impaction \\
\hline Part 19 & Sampling strategy for molds \\
\hline Part 20 & Detection and enumeration of molds-determination of total spore count \\
\hline Part 21 & Detection and enumeration of molds—sampling from materials \\
\hline Part 22 & Detection and enumeration of molds—molecular methods \\
\hline Part 23 & $\begin{array}{l}\text { Performance test for evaluating the reduction of formaldehyde concentrations by sorptive } \\
\text { building materials }\end{array}$ \\
\hline Part 24 & $\begin{array}{l}\text { Performance test for evaluating the reduction of volatile organic compound (except } \\
\text { formaldehyde) concentrations by sorptive building material }\end{array}$ \\
\hline Part 25 & $\begin{array}{l}\text { Determination of the emission of semi-volatile organic compounds by building } \\
\text { products-micro-chamber method }\end{array}$ \\
\hline Part 26 & Sampling strategy for carbon dioxide $\left(\mathrm{CO}_{2}\right)$ \\
\hline Part 27 & $\begin{array}{l}\text { Determination of settled fibrous dust on surfaces by SEM (scanning electron microscopy) } \\
\text { (direct method) }\end{array}$ \\
\hline Part 28 & Determination of odor emissions from building products using test chambers \\
\hline
\end{tabular}


Table 1. Cont.

\begin{tabular}{|c|c|}
\hline & EN ISO 16000 «Indoor Air » \\
\hline Part 29 & Test methods for VOC detectors \\
\hline Part 30 & Sensory testing of indoor air \\
\hline Part 31 & $\begin{array}{l}\text { Measurement of flame retardants and plasticizers based on organophosphorus } \\
\text { compounds-phosphoric acid ester }\end{array}$ \\
\hline Part 32 & Investigation of buildings for pollutants and other injurious factors-inspections \\
\hline Part 33 & Determination of phthalates with gas chromatography/mass spectrometry (GC/MS) \\
\hline Part 34 & General strategies for the measurement of airborne particle \\
\hline Part 35 & $\begin{array}{l}\text { Measurement of polybrominated diphenylether, hexabromocyclododecane, and } \\
\text { hexabromobenzene }\end{array}$ \\
\hline Part 36 & $\begin{array}{l}\text { Test method for the reduction rate of airborne bacteria by air purifiers using a test chamber } \\
\text { ISO } 16000\end{array}$ \\
\hline Part 37 & Strategies for the measurement of $\mathrm{PM}_{2.5}$ \\
\hline Part 38 & $\begin{array}{l}\text { Determination of amines in indoor and test chamber air-active sampling on samplers } \\
\text { containing phosphoric acid impregnated filters }\end{array}$ \\
\hline Part 39 & $\begin{array}{l}\text { Determination of amines-analysis of amines by (ultra-)high-performance liquid } \\
\text { chromatography coupled to high resolution or tandem mass spectrometry }\end{array}$ \\
\hline Part 40 & Indoor air quality management system \\
\hline
\end{tabular}

In some EU countries such as France, Belgium, Portugal, etc., there are specific legislations for each pollutant and the relative reference ISO standards to be used. The great confusion of these years has been precisely the absence of sampling and analysis standards dedicated to IAQ. Standards for industrial environments were often used, i.e., National Institute for Occupational Safety and Health (NIOSH), Occupational Safety and Health Administration (OSHA), etc.), which have $\mathrm{mg} \mathrm{m}^{-3}$ sensitivities (and have nothing to do with indoor $\mu \mathrm{g} \mathrm{m}^{-3}$ concentrations). Against this background, the adoption of the ISO 16000 standard represented a significant improvement as to the study and control activities.

Now, following behavior consolidated in several countries, it is, therefore, appropriate to develop indoor specific harmonized reference values in order to better manage particularly problematic situations in such environments. In the absence of specific national references to be used for a comparison, those reported by ad hoc working groups, or in the legislation of other European countries, are currently used.

Several EU countries, in recent years, have set up working groups with a specific mandate to develop guide values for air quality in confined spaces. Table 2 shows a series of guide values, present in the official documents, for selected pollutants, including those considered in the WHO guidelines.

For instance, Germany, by the German Working Group on Indoor Guideline Values of the Federal Environmental Agency and the States' Health Authorities (AG IRK/AOLG) [18], used a methodology starting from Lowest Observed Adverse Effect Level (LOAEL), or lower level of exposure to a toxic pollutant, for which negative health effects have been observed, introducing safety factors, such as inter- and intra-species. On the other hand, the UK adopted a different approach. In particular, the commission on the effects of air pollution on human health, i.e., the Committee on the Medical Effects of Air Pollutants (COMEAP) (updated in 2020) [19] and the Royal College of Pediatrics and Child Health (RCPCH) [20], developed guide values on the basis of WHO studies. France did the same, thanks to the collaboration between the French Scientific and Technical Center for Construction (CSTB) and the French Agency for Environmental and Occupational Health Safety (AFSSET) [21-23]. The working group developed a long series of studies to arrive at the elaboration of guide values for eight pollutants, such as hydrogen cyanide, carbon monoxide, benzene, formaldehyde, trichlorethylene, tetrachlorethylene, naphthalene, $\mathrm{PM}_{10}$ and $\mathrm{PM}_{2.5}$. This activity was part of the National Health and Environment Plan PNSE 2004-2008 [24], followed by the second National Plan for Health and Environment (PNSE 2) that was published for the period 2009-2013. Alongside the AFSSET indications, the authors would like to mention those identified by the High Council of Public Health-Haut Conseil de la Santé 
Publique (HCSP), which elaborated a series of documents on the values of action, and long-term for the evaluation of IAQ [25].

France implemented a plan of targeted interventions with the enactment of law no. 2010-788 of 12 July 2010, which is continuously updated (the last one in 2016), and establishes the obligation of periodic monitoring of the air quality in confined spaces, as well as the responsibility of the owners or occupants, gradually in force:

- from 1 January 2018 for confined spaces, such as leisure centers, swimming pools, health facilities, social services, and nurseries with children under 6 years of age;

- $\quad$ from 1 January 2018 for elementary education institutions;

- $\quad$ before 1 January 2020 for juvenile detention facilities and first- and second-degree education or vocational training institutions;

- $\quad$ from 1 January 2023 for all other indoor spaces.

For structures open to the public after these dates, the first periodic monitoring must be carried out no later than 31 December of the year, following the opening of the structure. Failure to comply with the terms of implementation of this obligation is punished with a fine. The control of the indoor environment through the monitoring of pollutants must be repeated every seven years, except in the case in which at least one of the pollutants measured during the monitoring shows levels higher than that foreseen in the aforementioned decrees. In this case, monitoring of the confined environment must be carried out within two years.

In addition, the Netherlands, using the studies performed by the National Institute for Public Health and the Environment (RIVM) [26], achieved guiding values starting from the Maximum Permissible Risk (MPR), which represents the level of exposure to a toxic substance for which there are no negative health effects.

Among the Nordic countries, in Finland, for example, the working group (coordinated by the Ministry of Social Affairs and Health (MSAH)), developed guide values for five pollutants: ammonia, carbon monoxide, carbon dioxide, hydrogen sulfide, and $\mathrm{PM}_{10}$. They were proposed in the decrees of the Ministry of the Environment Housing and Building Department D2 National Building Code of Finland-Indoor Climate and Ventilation of Buildings Regulations and Guidelines [27], which entered into force 1 October 2003. For the other pollutants, it is possible to derive guide values using $1 / 10$ of the limits for industrial work environments (Occupational Exposure Limit, OEL). If more pollutants are present, the formula is to be applied: $\Sigma\left(C_{i} /(H T P)_{i}\right)>0.1$, where $C_{i}$ is the measured concentration of a single pollutant and (HTP) is the occupational exposure limit of the pollutant in question. The guide values for confined spaces apply to buildings that are occupied for at least six months and where the ventilation system is kept constantly on. Alongside these references are those developed by the Finnish Society of Indoor Air Quality and Climate Classification [27]. It is an initiative desired and financed by the Ministry of the Environment, in collaboration with the experts of the manufacturers and stakeholders of the materials sector, which led to the identification of the target values defined as S1 (individual indoor environment), S2 (good indoor environment), and S3 (satisfactory indoor environment) categories [27].

Belgium, on the other hand, in the Flanders region, established by decree that entered into force on 1 October 2004, reference values for 15 pollutants: acetaldehyde, formaldehyde, total aldehydes, benzene, asbestos, carbon dioxide, nitrogen dioxide, toluene, ozone, carbon monoxide, volatile organic compounds, trichlorethylene, tetrachloroethylene, $\mathrm{PM}_{10}$ and $\mathrm{PM}_{2.5}$. For five of these pollutants, a category of concentration levels was also identified, defined as intervention values or concentrations of the pollutants corresponding to a level of maximum permissible risk that cannot be exceeded. Another interesting aspect present in the decree is that, in the event that an intervention on the field is requested by experts from the health inspectorate, and that the analytical results of this investigation highlights critical conditions linked to the negligence of the owner or occupant, the inspectorate charges the intervention costs to the applicant [28]. In 2019, further legislative acts were issued for office 
workplaces intended to welcome the public (decrees 31 January 2019, 2019/201064, and 21 May 2019, 2019/201857).

In the late 1990s, in Austria, the Ministry of the Environment in collaboration with the Academy of Sciences established an interdisciplinary working group for the drafting of guiding values for indoor environments, using a methodology starting from No-Observed-Adverse-Effect-Level (NOAEL) [29]. Using this approach, guide values of six substances were developed: formaldehyde, styrene, toluene, carbon dioxide, volatile organic compounds (VOCs), and trichlorethylene.

Portugal, in April 2006, by decree no. 79 of the Ministry of Public Works, Transport, and Communications [30], and in 2013 by decree no. 60 [31], set maximum reference concentrations for six pollutants: $\mathrm{PM}_{10}$, carbon dioxide, carbon monoxide, ozone, formaldehyde, total VOCs. The decree, in force since June 2006, also establishes the mandatory monitoring of the type and size of the building, and provides corrective actions within 30 days, if after the monitoring, the concentrations of pollutants present levels higher than reported in article 29 paragraph 8 of the decree. Further, the owner or tenant must also provide, within the following 30 days, the results obtained from the new measurements made. In case one of the above conditions is not met, the owner or tenant is subject to the penalties provided for in the decree, such as, for example, the immediate closure of the apartment or the payment of a fine.

In all countries, the proposed guide values are correlated by the relative sampling and analysis methods developed or implemented by the various national training bodies for correct evaluation (e.g., sampling and analysis strategies). These training bodies include the German Institute for Standardization (Deutsches Institut für Normung, DIN), Association Française de Normalization (AFNOR), Bureau de Normalization (NBN), Finnish Standards Association (SFS), Austrian Standards Institute (ASI), Nederlands Normalisatie Instituut (NEN), and the British Standards Institution (BSI). It should be noted that the guide or reference value must always be related to the sampling and analysis method to be adopted for its verification.

For all these countries, except Belgium, Finland, Lithuanian, Portugal, and France (for benzene, formaldehyde, carbon dioxide, and tetrachloroethylene), the recommended guide values have no legal value, even though, in practice they have reached considerable importance. These values, if properly used, can allow for better assessment of the IAQ.

Finally, IAQ is also important for protecting vulnerable materials, including cultural heritage in museums. Inside museums, libraries, and cultural environments—or storage of materials of historical and artistic interest - the quality of indoor air, together with the microclimate (temperature and relative humidity, which must mainly take into account the nature of the materials and goods), and the lighting (another important parameter that can enhance the phenomena of degradation of materials and goods), is fundamental for the management, conservation, and enhancement of goods and finds, and for the choice of measures to contain energy consumption and improve the quality of museum environments, for the health of workers and visitors. There are several reference sources for museum environments, such as the United Nations Educational, Scientific, and Cultural Organization (UNESCO), International Council of Museums (ICOM), International Center for the study of the preservation and restoration of cultural property (ICCROM), National Information Standards Organization (NISO), Getty Conservation Institute, Environmental Conditions for Exhibiting Library and Archival Materials, WHO, and the Ministry of Cultural Heritage and Activities (MIBACT, Italy), just to cite a few. Among the different documents, the authors would like to highlight the following:

WHO guidelines for some chemical and biological pollutants and the risks associated with the presence of humidity;

- EN 15758:2010 Conservation of Cultural Heritage-procedures and instruments for measuring the temperature of the air and that of the surface of objects;

EN 15759:2011 Conservation of cultural heritage-indoor climate-part 2: management of ventilation for the protection of buildings belonging to the cultural heritage and collections; 
EN 15759-2:2018 Conservation of cultural heritage-indoor climate-part 2: ventilation management for the protection of cultural heritage buildings and collections;

EN 15898:2019 Conservation of cultural heritage-general terms and definitions;

EN 16141:2012 Conservation of cultural heritage-guidelines for the management of environmental conditions in the storage areas of museum collections and plant engineering: definition and characteristics of collection centers for the preservation and management of cultural heritage;

EN 16242:2012 Conservation of cultural heritage-procedures and instruments for measuring the humidity of the air and the exchange of steam between the air and the assets cultural heritage;

○ EN 16682:2017 Conservation of cultural heritage-methods of measurement of moisture content, or water content, in materials constituting immovable cultural heritage;

- EN 16853:2017 Conservation of cultural heritage-conservation process-decision making, planning, and implementation;

- EN 16883:2017 Conservation of cultural heritage-guidelines for improving the energy performance of historic buildings;

EN 16893:2018 Conservation of Cultural Heritage-specifications for location, construction, and modification of buildings or rooms intended for the storage or use of heritage collections.

The adoption of these rules constitutes a significant improvement compared to what has been achieved so far in the study and control activities; the standardization of the methods also increases the possibility of a correct comparison between the different data produced at the European level. 
Table 2. Indoor air contaminants: reference values used in some European countries, guide values, and unitary risk of the World Health Organization (WHO).

\begin{tabular}{|c|c|c|c|c|c|c|c|c|c|c|c|c|c|c|}
\hline $\begin{array}{l}\text { Contaminant } \\
\text { (Unit of } \\
\text { Measurement) }\end{array}$ & $\begin{array}{c}\text { WHO } \\
\text { Guidelines } \\
\left.\text { (Outdoor }^{2}\right)\end{array}$ & $\begin{array}{c}\text { WHO } \\
\text { Guidelines } \\
\left(\text { Indoor }{ }^{2}\right)\end{array}$ & France & Germany & Netherlands & $\begin{array}{l}\text { United } \\
\text { Kingdom }\end{array}$ & $\begin{array}{l}\text { Belgium } \\
\text { (Flanders) }\end{array}$ & Finland $^{c}$ & Austria & Portugal & Norway & Lithuania & $\begin{array}{c}\text { Poland } \\
\text { (Residential) }\end{array}$ & $\begin{array}{l}\text { Poland } \\
\text { (Public } \\
\text { Offices) }\end{array}$ \\
\hline Reference & {$[32,33]$} & [34] & [21-25] & {$[18]$} & [26] & [20] & [28] & [27] & [29] & [30] & [35] & [36] & [37] & {$[37]$} \\
\hline $\begin{array}{l}\text { Benzene } \\
\left({\mu g^{-3}}^{-3}\right)\end{array}$ & $\begin{array}{l}0.17 \text { (UR/lt) } 10^{-6} \\
1.7(\mathrm{UR} / \mathrm{lt}) 10^{-5}\end{array}$ & $\begin{array}{l}0.17 \text { (UR/lt) } 10^{-6} \\
1.7 \text { (UR/lt) } 10^{-5}\end{array}$ & $\begin{array}{c}30(24 \mathrm{~h}) \\
10(1 \mathrm{y}) \\
\text { RA: } 10 \\
\text { LP: } 2 \\
0.2 \text { (UR/lt) } 10^{-6} \\
2 \text { (UR/It) } 10^{-5}\end{array}$ & - & 20 & $5(1 \mathrm{y})$ & $\begin{array}{l}\mathrm{GV} \leq 2 \\
\mathrm{IV} 10\end{array}$ & - & - & $5(8 \mathrm{~h})$ & - & - & $10(24 \mathrm{~h})$ & $20(8 \mathrm{~h})$ \\
\hline $\begin{array}{l}\text { Formaldehyde } \\
\left(\mu \mathrm{g} \mathrm{m}^{-3}\right)\end{array}$ & $100(30 \mathrm{~m})$ & $100(30 \mathrm{~m})$ & $\begin{array}{c}50(2 \mathrm{~h}) \\
10(\mathrm{y}) \\
30 \text { (10 from 2023) } \\
\text { RA: } 100 \\
\text { LP: } 10 \\
\end{array}$ & 120 & $\begin{array}{l}120(30 \mathrm{~m}) \\
10(1 \mathrm{y}) \\
1.2(\mathrm{LP})\end{array}$ & $100(30 \mathrm{~m})$ & $\begin{array}{l}\text { GV10 }(30 \mathrm{~m}) \\
\text { IV100 }(30 \mathrm{~m})\end{array}$ & 50 & $\begin{array}{l}100(30 \mathrm{~m}) \\
60(24 \mathrm{~h})\end{array}$ & $100(8 \mathrm{~h})$ & $100(30 \mathrm{~m})$ & 100 & $50(24 \mathrm{~h})$ & $100(8 \mathrm{~h})$ \\
\hline $\begin{array}{l}\mathrm{CO} \\
\left(\mathrm{mg} \mathrm{m}^{-3}\right)\end{array}$ & $\begin{array}{l}100(15 \mathrm{~m}) \\
60(30 \mathrm{~m}) \\
30(1 \mathrm{~h}) \\
10(8 \mathrm{~h})\end{array}$ & $\begin{array}{l}100(15 \mathrm{~m}) \\
35(1 \mathrm{~h}) \\
10(8 \mathrm{~h}) \\
7(24 \mathrm{~h})\end{array}$ & $\begin{array}{l}100(15 \mathrm{~m}) \\
60(30 \mathrm{~m}) \\
30(\mathrm{~h}) \\
10(8 \mathrm{~h})\end{array}$ & $\begin{array}{c}1.5(8 \mathrm{~h}) \text { RWI } \\
6(30 \mathrm{~m}) \text { RWI } \\
60(30 \mathrm{~m}) \\
\text { RWII } \\
15(8 \mathrm{~h}) \text { RWII }\end{array}$ & $\begin{array}{l}100(15 \mathrm{~m}) \\
60(30 \mathrm{~m}) \\
30(\mathrm{~h} \mathrm{~h}) \\
10(8 \mathrm{~h})\end{array}$ & $\begin{array}{l}100(15 \mathrm{~m}) \\
60(30 \mathrm{~m}) \\
30(1 \mathrm{~h}) \\
10(8 \mathrm{~h})\end{array}$ & $\begin{array}{l}\text { GV } 5.7(24 \mathrm{~h}) \\
\text { IV } 30(1 \mathrm{~h})\end{array}$ & 8 & - & $10(8 \mathrm{~h})$ & $\begin{array}{l}25(1 \mathrm{~h}) \\
10(8 \mathrm{~h})\end{array}$ & 10 & $25(1 \mathrm{~h})$ & $10(8 \mathrm{~h})$ \\
\hline $\begin{array}{l}\mathrm{NO}_{2} \\
\left(\mu \mathrm{g} \mathrm{m}^{-3}\right)\end{array}$ & $\begin{array}{l}200(1 \mathrm{~h}) \\
40(1 \mathrm{y})\end{array}$ & $\begin{array}{l}200(1 \mathrm{~h}) \\
40(1 \mathrm{y})\end{array}$ & $\begin{array}{l}200(1 \mathrm{~h}) \\
40(1 \mathrm{y})\end{array}$ & $\begin{array}{c}350(30 \mathrm{~m}) \\
\text { RWII } \\
60 \text { (7 d) RWII }\end{array}$ & $\begin{array}{l}200(1 \mathrm{~h}) \\
40(1 \mathrm{y})\end{array}$ & $\begin{array}{l}300(1 \mathrm{~h}) \\
40(1 \mathrm{y})\end{array}$ & $\begin{array}{l}\text { GV } 135(1 \mathrm{~h}) \\
\text { IV } 200(1 \mathrm{~h})\end{array}$ & - & - & - & $\begin{array}{l}200(1 \mathrm{~h}) \\
100(24 \mathrm{~h})\end{array}$ & - & - & - \\
\hline $\begin{array}{l}\text { Naphthalene } \\
\left(\mu \mathrm{g} \mathrm{m}^{-3}\right)\end{array}$ & - & $10(1 \mathrm{y})$ & $10(1 \mathrm{y})$ & $\begin{array}{c}20 \text { (7 d) RWI } \\
200 \text { (7 d) RWII }\end{array}$ & 25 & - & - & - & - & - & - & - & $100(24 \mathrm{~h})$ & $150(8 \mathrm{~h})$ \\
\hline $\begin{array}{l}\text { Styrene } \\
\left(\mathrm{\mu g} \mathrm{m}^{-3}\right)\end{array}$ & $260(7 \mathrm{~d}) 70(30 \mathrm{~m})$ & - & - & $\begin{array}{c}30 \text { (7 d) RWI } \\
300 \text { (7 d) RWII }\end{array}$ & 900 & - & - & 1 & $\begin{array}{l}40(7 \mathrm{~d}) \\
10(1 \mathrm{~h}) \\
\end{array}$ & - & - & - & $20(24 \mathrm{~h})$ & $30(8 \mathrm{~h})$ \\
\hline $\begin{array}{l}\text { PAHs (as BaP) } \\
\left(\mathrm{ng} \mathrm{m}^{-3}\right)\end{array}$ & $\begin{array}{c}0.012 \mathrm{ng} \mathrm{m}^{-3} \\
\text { (UR//t) 10-6 } \\
0.12 \mathrm{ng} \mathrm{m}^{-3} \text { (UR/t) } \\
10^{-5}\end{array}$ & $\begin{array}{c}0.012 \mathrm{ng} \mathrm{m}^{-3} \\
\text { (UR/lt) } 10^{-6} \\
0.12 \mathrm{ng} \mathrm{m}^{-3} \text { (UR//t) } \\
10^{-5}\end{array}$ & - & - & 1.2 & $0.25(1 \mathrm{y})$ & - & - & - & - & - & - & - & - \\
\hline $\begin{array}{l}\text { Tetrachloroethylene } \\
\left(\mathrm{\mu g} \mathrm{m}^{-3}\right)\end{array}$ & $\begin{array}{c}250(1 \mathrm{y}) \\
8000(30 \mathrm{~m})\end{array}$ & $250(1 \mathrm{y})$ & $\begin{array}{l}1380(1-14 \mathrm{~d}) \\
250(1 \mathrm{y}) \\
\text { RV: } 250 \\
\text { LP: } 250\end{array}$ & $1(7 \mathrm{~d})$ & 250 & - & 100 & - & 250 (7 d) & $250(8 \mathrm{~h})$ & - & - & - & - \\
\hline $\begin{array}{l}\text { Trichloroethylene }{ }^{\mathrm{b}} \\
\left(\mathrm{gg} \mathrm{m}^{-3}\right)\end{array}$ & $\begin{array}{c}2.3 \mu \mathrm{g} \mathrm{m}^{-3} \text { (UR/ff) } \\
10^{-6} \mathrm{UR} / \mathrm{f} \\
23 \mu \mathrm{m} \mathrm{m}^{-3} \text { (UR/ff) } \\
10^{-5}\end{array}$ & $\begin{array}{c}2.3 \mu \mathrm{g} \mathrm{m}^{-3} \text { (UR//f) } \\
10^{-6} \\
23 \mu \mathrm{m}^{-3} \\
1^{-5} \\
\text { (UR//f) }\end{array}$ & $\begin{array}{c}800\left(14 \mathrm{~d}^{-1} \mathrm{y}\right) \\
\text { RA: } 10 \\
\text { RV: } 2 \\
\text { LP: } 2.0 \text { (UR/lt) } 10^{-6} \\
20 \text { (UR//t) } 10^{-5}\end{array}$ & $1(7 \mathrm{~d})$ & - & - & 200 & - & - & $25(8 \mathrm{~h})$ & - & - & $150(24 \mathrm{~h})$ & $200(8 \mathrm{~h})$ \\
\hline $\begin{array}{l}\text { Dichloromethane } \\
\left(\mathrm{\mu g} \mathrm{m}^{-3}\right)\end{array}$ & $\begin{array}{l}3000(24 \mathrm{~h}) \\
450(7 \mathrm{~d})\end{array}$ & - & & $\begin{array}{c}200(24 \mathrm{~h}) \\
\text { RWI } \\
2000(24 \mathrm{~h}) \\
\text { RWII }\end{array}$ & $200(1 \mathrm{y})$ & - & - & - & - & - & - & - & - & - \\
\hline
\end{tabular}


Table 2. Cont.

\begin{tabular}{|c|c|c|c|c|c|c|c|c|c|c|c|c|c|c|}
\hline $\begin{array}{l}\text { Contaminant } \\
\text { (Unit of } \\
\text { Measurement) }\end{array}$ & $\begin{array}{c}\text { WHO } \\
\text { Guidelines } \\
\left(\text { (Outdoor }^{2}\right)\end{array}$ & $\begin{array}{c}\text { WHO } \\
\text { Guidelines } \\
\text { (Indoor }{ }^{\text {a) }} \text { ) }\end{array}$ & France & Germany & Netherlands & $\begin{array}{c}\text { United } \\
\text { Kingdom }\end{array}$ & $\begin{array}{c}\text { Belgium } \\
\text { (Flanders) }\end{array}$ & Finland $^{c}$ & Austria & Portugal & Norway & Lithuania & $\begin{array}{c}\text { Poland } \\
\text { (Residential) }\end{array}$ & $\begin{array}{l}\text { Poland } \\
\text { (Public } \\
\text { Offices) }\end{array}$ \\
\hline $\begin{array}{l}\text { Toluene } \\
\left(\mu \mathrm{g} \mathrm{m}^{-3}\right)\end{array}$ & $\begin{array}{c}260(7 \mathrm{~d}) \\
1000(30 \mathrm{~m})\end{array}$ & - & - & $\begin{array}{c}300(1-14 \mathrm{~d}) \\
\text { RWI } \\
3000(1-14 \mathrm{~d}) \\
\text { RWII }\end{array}$ & $200(1 \mathrm{y})$ & - & 260 & - & 75 (1 h) & $250(8 \mathrm{~h})$ & - & - & $200(24 \mathrm{~h})$ & $250(8 \mathrm{~h})$ \\
\hline $\begin{array}{l}\text { Total VOCS } \\
\left(\mathrm{\mu g} \mathrm{m}^{-3}\right)\end{array}$ & - & - & - & - & $200(1 \mathrm{y})$ & - & 200 & - & - & $600(8 \mathrm{~h})$ & 400 & 600 & 400 & - \\
\hline $\begin{array}{l}\mathrm{PM}_{10} \\
\left(\mu \mathrm{g} \mathrm{m}^{-3}\right)\end{array}$ & $\begin{array}{l}50(24 \mathrm{~h}) \\
20(1 \mathrm{y})\end{array}$ & - & $\begin{array}{l}50(24 \mathrm{~h}) \\
20(1 \mathrm{y}) \\
\text { RA: } 75 \\
\text { LP: } 15\end{array}$ & - & $\begin{array}{l}50(24 \mathrm{~h}) \\
20(1 \mathrm{y})\end{array}$ & - & $40(24 \mathrm{~h})$ & 50 & - & $50(8 \mathrm{~h})$ & $90(8 \mathrm{~h})$ & 100 & $90(8 \mathrm{~h})$ & - \\
\hline $\begin{array}{l}\mathrm{PM}_{2.5} \\
\left(\mu \mathrm{g} \mathrm{m}^{-3}\right)\end{array}$ & $\begin{array}{l}25(24 \mathrm{~h}) \\
10(1 \mathrm{y})\end{array}$ & - & $\begin{array}{l}25(24 \mathrm{~h}) \\
10(1 \mathrm{y}) \\
\text { RA: } 50 \\
\text { LP: } 10\end{array}$ & $25(24 \mathrm{~h})$ & $\begin{array}{l}25(24 \mathrm{~h}) \\
10(1 \mathrm{y})\end{array}$ & - & $15(1 \mathrm{y})$ & - & - & $25(8 \mathrm{~h})$ & $40(8 \mathrm{~h})$ & - & $40(8 \mathrm{~h})$ & - \\
\hline
\end{tabular}

${ }^{a}$ the indoor air quality guide values indicate the concentration levels in the air of the pollutants, associated with the exposure times, to which adverse health effects are not expected, in regards to non-carcinogenic pollutants; ${ }^{\mathrm{b}}$ the upper-bound excess lifetime cancer risk estimated to result from continuous exposure to an agent at a concentration of $1 \mu \mathrm{g} \mathrm{m}^{-3}$ in air (or $1 \mu \mathrm{g}$ $\mathrm{L}^{-1}$ in water); ${ }^{\mathrm{C}}$ the guide values for indoor environments apply to buildings that are occupied for at least six months and where the ventilation system is kept constantly on. Abbreviations: UR unit risk; lt lifetime; RA rapid action; LP long period; RW I (all-day use) and RW II (danger threshold) German guide values (Richtwert); GV guideline value; IV intervention value; RV reference value; PAHs Polycyclic Aromatic Hydrocarbons; BaP Benzo[a]pyrene; VOCs Volatile Organic Compounds; y year; $d$ day; $h$ hour; $m$ minute. 


\section{The Italian Situation}

Among the Member States of the EU, Italy plays an important role, as evidenced by the $10.4 \%$ of publications in the IAQ field during the last two decades (Figure 1). The Italian situation is particularly interesting because, unlike the other countries, in the Italian legislation, there is no specific reference relating to residential IAQ, even if pre-regulatory initiatives have multiplied.

In relation to IAQ, in almost all European countries, a legislative delay has been compulsorily and quickly filled. This delay has to be covered, with the issue of specific acts containing suitable references for chemical and biological pollutants, in line with those developed by the WHO, with the most recent and user-friendly specific protocols and procedures provided by the ISO 16000 indoor air standard in its various parts. For these reasons, in 2010, the National Study Group (GdS) on Indoor Air Pollution was established at the Italian Institute of Health (IIS), in which the various ministerial components are represented (Ministry of Health, Ministry of the Environment and Protection of the Territory and the Sea, Ministry of Labor and Social Policies), regions, local authorities and research institutes (IIS, National Research Council (CNR), Italian National Agency for New Technologies, Energy, and the Sustainable Economic Development (ENEA), Italian Institute for Environmental Protection and Research (ISPRA), National System for Environmental Protection (SNPA), and the National Institute for Insurance against Accidents at Work (INAIL). The GdS-ISS is working to provide shared technical-scientific documents in order to allow harmonized actions at national level in order to improve the correct assessment of indoor air pollution. The documents of the GdS-ISS, published as Rapporti ISTISAN, or dissemination documents, include recommendations to prevent indoor air pollution, to improve behavior, cultural awareness, training, to reduce exposure and effects on health, and to increase economic competitiveness.

The GdS-ISS has developed eight reference documents for the monitoring strategies of the main indoor chemical and biological pollutants, the role of the different sources, the energy efficiency activities, and the different indoor combustion [38-48]. Table 3 shows the list of ISTISAN reports already published by the GdS-ISS. Some of the technical indications can already be used for the definition of a national plan on indoor air quality and constitute an important reference for the country.

Table 3. Rapporti ISTISAN just published by the National Study Group (GdS) on Indoor Pollution.

\begin{tabular}{|c|c|c|}
\hline & Title & Ref. \\
\hline Rapp. ISTISAN & $\begin{array}{c}\text { Monitoring strategies for volatile organic compounds (VOCs) in indoor } \\
\text { environments }\end{array}$ & [38] \\
\hline Rapp. ISTISAN & Monitoring strategies of biological air pollution in indoor environment & [39] \\
\hline Rapp. ISTISAN & $\begin{array}{c}\text { Proceedings of the Workshop "Indoor air pollution: current situation in } \\
\text { Italy". Rome, } 25 \text { June } 2012\end{array}$ & [40] \\
\hline Rapp. ISTISAN & $\begin{array}{l}\text { Proceedings of the Workshop "Indoor air quality: current national and } \\
\text { European situation. The expertise of the National Working Group on } \\
\text { indoor air". Rome, } 28 \text { May } 2014\end{array}$ & [41] \\
\hline Rapp. ISTISAN & $\begin{array}{l}\text { Monitoring strategies to assess the concentration of airborne asbestos } \\
\text { and man-made vitreous fibers in the indoor environment }\end{array}$ & [42] \\
\hline Rapp. ISTISAN & Microclimate parameters and indoor air pollution & [43] \\
\hline Rapp. ISTISAN & $\begin{array}{c}\text { Presence of } \mathrm{CO}_{2} \text { and } \mathrm{H}_{2} \mathrm{~S} \text { in indoor environments: current knowledge } \\
\text { and scientific field literature }\end{array}$ & [44] \\
\hline Rapp. ISTISAN & $\begin{array}{l}\text { Monitoring strategies to } \mathrm{PM}_{10} \text { and } \mathrm{PM}_{2.5} \text { in indoor environments: } \\
\text { characterization of inorganic and organic micro-pollutants }\end{array}$ & [45] \\
\hline Rapp. ISTISAN & $\begin{array}{c}\text { Natural radioactivity in building materials in the European Union: a } \\
\text { database of activity concentrations, radon emanations and radon } \\
\text { exhalation rates }{ }^{1}\end{array}$ & [46] \\
\hline Rapp. ISTISAN & $\begin{array}{l}\text { Indoor air quality in healthcare environments: strategies for monitoring } \\
\text { chemical and biological pollutants }\end{array}$ & [47] \\
\hline & & [48] \\
\hline
\end{tabular}

${ }^{1}$ This publication is not authored by the GdS, but it contains issues related to the IAQ. 
The results of this activity have been included in the Directive of the President of the Council of Ministers 1 June 2017 published in the Official Journal on 17 July 2017, among the mandatory training activities that the employer must provide to workers. Such activities of the GdS-ISS have also been taken up in the Air Pollution Strategy of the WHO Country Profile for Italy. In this way, an informative booklet entitled "Air in our home: how to improve it" was prepared, which illustrates the origin of indoor air pollution, the role of sources (household cleaning products, construction products, furniture, fabrics, incense sticks, scented candles, stoves, etc.), and the contribution of individual behaviors, providing specific recommendations to reduce indoor pollution levels.

Work is currently in progress for the preparation of two new documents on indoor air quality in office environments and on contaminated sites. On the other hand, ISTISAN reports are being published that address the problems of indoor air quality in school and health facilities, with the identification of specific environmental detection methodologies and possible sanitary implications.

In 2018, Pierpaoli and Ruello published a paper on the bibliometric study on the IAQ [49]: the authors asked the question "What are the actual trends in Indoor Air Quality (IAQ), and in which direction is academic interest moving?" Starting from that, the authors analyzed the worldwide literature from 1990 to 2018, using the Web of Science as a database. They identified past trends and current advances in IAQ, as well as the issues that were expected to be pertinent in the future. In this section, we would like to show state-of-the-art research in the IAQ sector in Italy from previous years, considering what is shown in Figure 1: 243 scientific papers in specialized journals have been published in Italy since 2015. The topics cover different subjects, i.e. environmental science, engineering, medicine, social sciences, energy, physics and astronomy, biochemistry, genetics and molecular biology, materials science, chemistry, chemical engineering, earth and planetary sciences, agricultural and biological sciences, immunology and microbiology, pharmacology, toxicology and pharmaceutics, computer science, mathematics, business, management and accounting, economics, econometrics and finance, arts and humanities, decision sciences, multidisciplinary, and nursing. This means there is a large interest by the scientific community in this field.

Most papers are addressed to investigate the IAQ in schools. Such topics are important because, based on the subpopulation interested, such as suggested by Manigrasso et al. [50], which estimated the particle regional respiratory doses for both combustion and non-combustion aerosol sources currently encountered in microenvironments, with special regards to the age of subjects. Recent papers on school environments are related to monitoring $\mathrm{PM}, \mathrm{NO}_{\mathrm{x}}, \mathrm{VOCs}$, and $\mathrm{CO}_{2}$, with regard to the ventilation efficiency and the energy consumption [51-56]. As to the radon exposure, according to two papers, the schools are vulnerable targets due to the long daily childhood presence, and the radon risk could be reduced by low-cost interventions (e.g., implementation of natural air ventilation and school maintenance) $[57,58]$. Over the last five years, several papers were published on residential IAQ: the authors would like to highlight the main papers of interest. Different research groups dealt the problems related to wood or biomass burning, evidencing the emissions and the related risk assessment [59-61]. Particular attention has been addressed to hospitals and healing places for defining protocol for inpatient rooms, to understand the state-of-the-art research and for suggesting design and management strategies for improving process quality [62,63]. Indoors, there are different combustion and non-combustion sources. Manigrasso et al. revised all of the possible sources and investigated the ultrafine particle emissions and relative doses deposited in the human respiratory tract [64-66]. The importance of the micro-climatic parameters was discussed by Zanni et al., which monitored the IAQ in the airport of Bologna (Italy) as a prototypal example of a large regional airport [67]. Siani et al. applied the cluster analysis on a long time series of temperature and relative humidity measurements for identifying the thermo-hygrometric features in a museum [68]. Cincinelli et al. characterized the IAQ in libraries and archives in Florence (Italy), evidencing that benzene, toluene, ethylbenzene, and xylenes (BTEXs) are the most abundant VOCs, along with cyclic volatile methylsiloxanes, aldehydes, terpenes, and organic acids. In particular, the authors detected presence of acetic acid, which is a chemical that can oxidize books and other exposed objects, and furfural, which is a known marker of 
paper degradation [69]. Tirler and Settimo discussed the increasing use of incense, magic candles, and other flameless products that may represent a health risk for humans. Pollutants, such as benzene and $\mathrm{PM}_{10}$ are mainly affected when these products are used indoors (for instance, the benzene concentration ranged from background levels to over $200 \mu \mathrm{g} \mathrm{m}^{-3}$ after the incense sticks had been tested) [70].

As can be seen, one of the main focal points of the authors is the relationship between IAQ and energy consumption, which is very important. However, it should be considered that the plans and/or interventions of restructuring or renovation cannot be only oriented to the theme of insulation, containment, and energy efficiency, which can alter or worsen air quality, microclimatic conditions, and natural ventilation. They should follow approaches allowing an overall improvement in air quality, with criteria to promote and guarantee health, primarily, to offer all of the maximum benefits of the most current quality educational and training models, and to obtain savings in management costs. Similarly, the same approach should be followed in cases of complete plant adaptations or restructuring (water, electricity, heat, fire, etc.).

\section{Conclusions}

The IAQ determinants on human health and the potential presence of harmful contaminants released from indoor sources have always been stressed by WHO in its technical documents and position papers. In Europe, specific directive legislative framework on the quality of indoor air is not yet available. Despite an increasing number of pre-legislative initiatives, guidelines, and documents, a harmonized and global approach is still missing. Pending a European directive on indoor air quality, as already done with outdoor air (e.g., 2008/50), which takes into account the WHO indications, this paper aims to provide an overview of the main technical-scientific references in order to allow harmonized actions and to cope with the main issues in such environments. In fact, often in the absence of specific national references to be used for comparison, surveillance actions in indoor environments are limited. The paper, gathering the main references to be used (reported by ad hoc working groups, or in legislation of other European countries, or, by analogy, with other standards, such as those relating to ambient air), means to assist operators engaged in prevention actions to implement interventions in different indoor environments. It should be remembered that these values represent the parameters to which reference must be made for an assessment of the inhalation risk of workers and the population. They are not the only ones, because specific exposure and vulnerability conditions are fundamental elements to consider for a correct risk assessment.

There is an urgent need for a change that is innovative, with a systemic, multidisciplinary approach based on skills. Nowadays, in the various member states, apart from the strong national differences, this situation entails a hygiene-health and environmental protection gap among the various countries (e.g., absence of standards and controls). To fill this gap, harmonization initiatives must be carried out, simultaneously establishing the elements (e.g., strategies, sampling, and analytical methods) and the parameters that must be considered for the control of pollutants indoors. There is no doubt that the heterogeneity of this current regulation system has led to a lack of comparability among the EU member states, both in terms of technical procedures and of health evaluation. Nonetheless, in some EU countries, regulations have been drawn up or recommendations have been developed on IAQ that can allow proper exposure assessment of the general population and the related health risks. Recently, the EU has also taken on a series of new commitments on the energy efficiency and the construction quality. In this regard, in the "Report from the Commission to the European Parliament and the Council: financial support for energy efficiency in buildings" [71] it is emphasized that improving the energy efficiency of buildings also entails important collateral benefits, including greater health.

In Italian territory, there is no reference legislation, but several commissions and working groups are at work. Among these, there is the National Study Group (activated by the ISS), which is working to provide concrete technical contribution for operators in the public and private sectors engaged in the indoor theme, in order to allow a homogeneous action at a national level. The results may lead to appropriate public health strategies aimed at reducing exposure in indoor environments. 
Author Contributions: Conceptualization, G.S. and P.A.; methodology, G.S.; software, M.M.; validation, M.M.; data curation, M.M.; writing—original draft preparation, G.G. and P.A.; writing-review and editing, G.S. and P.A.; visualization, P.A.; supervision, G.G. All authors have read and agreed to the published version of the manuscript.

Funding: This research received no external funding.

Conflicts of Interest: The authors declare no conflict of interest.

\section{References}

1. Suess, M.J. The Indoor Air Quality programme of the WHO regional office for Europe. Indoor Air 1992, 2, 180-193. [CrossRef]

2. Mølhave, L.; Krzyzanowski, M. The right to healthy indoor air: Status by 2002. Indoor Air 2003, 13, 50-53. [CrossRef] [PubMed]

3. Braubach, M.; Krzyzanowski, M. Development and status of WHO indoor air quality guidelines. In Proceedings of the 9th International Healthy Buildings Conference and Exhibition HB2009, Syracuse, NY, USA, 13-17 September 2009. Abstract Code 94942.

4. Tham, S.; Thompson, R.; Landeg, O.; Murray, K.A.; Waite, T. Indoor temperature and health: A global systematic review. Public Health 2020, 179, 9-17. [CrossRef] [PubMed]

5. Smith, A.; Pitt, M. Sustainable workplaces and building user comfort and satisfaction. J. Corp. Real Estate 2011, 13, 144-156. [CrossRef]

6. Mitova, M.I.; Cluse, C.; Goujon-Ginglinger, C.G.; Kleinhans, S.; Rotach, M.; Tharin, M. Human chemical signature: Investigation on the influence of human presence and selected activities on concentrations of airborne constituents. Environ. Pollut. 2020, 257, 113518. [CrossRef] [PubMed]

7. Sekar, A.; Varghese, G.K.; Ravi Varma, M.K. Analysis of benzene air quality standards, monitoring methods and concentrations in indoor and outdoor environment. Heliyon 2019, 5, e02918. [CrossRef] [PubMed]

8. Simanic, B.; Nordquist, B.; Bagge, H.; Johansson, D. Indoor air temperatures, $\mathrm{CO}_{2}$ concentrations and ventilation rates: Long-term measurements in newly built low-energy schools in Sweden. J. Build. Eng. 2019, 25, 100827. [CrossRef]

9. Kane, S.; Mahal, A. Cost-effective treatment, prevention and management of chronic respiratory conditions: A continuing challenge. Respirology 2018, 23, 799-800. [CrossRef]

10. Tang, H.; Ding, Y.; Singer, B. Interactions and comprehensive effect of indoor environmental quality factors on occupant satisfaction. Build. Environ. 2020, 167, 106462. [CrossRef]

11. Fabianova, E.; Fletcher, T.; Koppova, K.; Hruba, F.; Houthuijs, D.; Antonova, T.; Volf, J.; Rudnai, P.; Zejda, J.; Niciu, E. On indoor air in Central Europe. 2001. Available online: https://researchonline.lshtm.ac.uk/id/epri nt/16961 (accessed on 29 January 2020).

12. Olesen, B.W. Revision of EN 15251: Indoor Environmental Criteria. REHVA J. August 2012. Available online: https://www.rehva.eu/rehva-journal/chapter/revision-of-en-15251-indoor-environmental-c riteria (accessed on 29 January 2020).

13. Settimo, G.; D'Alessandro, D. European community guidelines and standards in indoor air quality: What proposals for Italy. Epidemiol. Prev. 2014, 38, 36-41.

14. Kunkel, S.; Kontonasiou, E.; Arcipowska, A.; Mariottini, F.; Atanasiu, B. Indoor Air Quality, Thermal, Comfort and Daylight; Buildings Performance Institute Europe (BPIE): Brussels, Belgium, 2015; ISBN 9789491143106. Available online: http://bpie.eu/uploads/lib/document/attachment/121/BPIE__IndoorAirQuality2015.pdf (accessed on 29 January 2020).

15. World Health Organization (WHO). Indoor Air Pollutants Exposure and Health Effects Report on a WHO Meeting Nördlingen, 8-11 June 1982. (EURO reports and studies; 78); WHO: Copenhagen, Denmark, 1982.

16. Scientific Committee on Health and Environmental Risks (SCHER). Preliminary Report on Risk Assessment on Indoor Air Quality. 31 January 2007. Available online: https:/ec.europa.eu/health/archive/ph_risk/comm ittees/04_scher/docs/scher_o_048.pdf (accessed on 29 January 2020).

17. EN ISO 16000:2006. Indoor air; European Committee for Standardization: Brussels, Belgium, 2006. 
18. Innenraumlufthygiene-Kommission and the permanent woirkng group of the Highest State Health Authorities (Arbeitsgemeinschaft der Obersten Landesgesundheitsbehörden, AOLG). Ad-Hoc Working Group for Indoor Air Guide Values. Umwelt Bundesamt. 1993. Available online: http://www.umweltbundesamt.de/en/topi cs/health/commissions-working-groups/ad-hoc-working-group-for-indoor-air-guide-values (accessed on 27 January 2020).

19. Public Health England. Indoor Air Quality Guidelines for Selected Volatile Organic Compounds (VOCs) in the UK. 2019. Available online: https://www.gov.uk/government/publications/air-quality-uk-guidelines-for -volatile-organic-compounds-in-indoor-spaces (accessed on 28 January 2020).

20. Royal College of Paedriatics and Child Health (RCPCH). Health Effects of Indoor Quality on Children and Young People. 2020. Available online: https:/www.rcpch.ac.uk/sites/default/files/2020-01/the-inside-storyreport_january-2020.pdf (accessed on 18 February 2020).

21. Agence Nationale de Securitè Sanitaire l'alimentation, de l'environnement et du travail. Valeurs Guides de qualité d'Air Intérieur (VGAI). Le Directeur Général Maisons-Alfort, ANSES. 2011. Available online: http://www.anses.fr/fr/content/valeurs-guides-de-qualit $\%$ C3\%A9-d $\%$ E2\%80\%99air-int $\% \mathrm{C}$ 3\%A9rieur-vgai (accessed on 28 January 2020).

22. France. Décret $n^{\circ}$ 2011-1727 du 2 décembre 2011 relatif aux valeurs-guides pour l'air intérieur pour le formaldéhyde et le benzene. J. Officiel République Française 2011. Available online: https://www.legifrance.g ouv.fr/affichTexte.do?cidTexte=JORFTEXT000024909119\&categorieLien=id (accessed on 2 December 2011).

23. France. Décret $n^{\circ}$ 2011-1728 du 2 décembre 2011 relatif à la surveillance de la qualité de l'air intérieur dans certains établissements recevant du public. J. Officiel République Française. 2011. Available online: https: //www.legifrance.gouv.fr/affichTexte.do?cidTexte=JORFTEXT000024909128 (accessed on 2 December 2011).

24. Lafon, D. Plan national santé environnement: 2004-2008 National plan for health and environnement. Arch. Mal. Prof. Environ. 2005, 66, 360-368.

25. Haut Conseil de la Santé publique (HCSP). Valeurs Reperes D'aide a la gestion dans l'air des espaces clos. Le formaldehyde; Ministère de la Santè et des Sports: Paris, France, 2009.

26. RIVM-National Institute for Public Health and the Environment. Health-Based Guideline Values for the Indoor Environment (Report 609021044/2007); RIVM: Bilthoven, The Netherlands, 2007.

27. Ahola, M.; Säteri, I.; Sariola, L. Revised Finnish classification of indoor climate 2018. E3S Web Conf. 2019, 111, 02017. [CrossRef]

28. Hoge Gezondheidsraad. Indoor air quality in Belgium. HGR: Brussel. 2017; Advies nr. 8794. Available online: https:/www.health.belgium.be/sites/default/files/uploads/fields/fpshealth_theme_file/ hgr_8794_advice_iaq.pdf (accessed on 28 January 2020).

29. Bundesministerium für Land- und Forstwirtschaft, Umwelt und Wasserwirtschaft \& Österreichischen Akademie Der Wissenschaften-BMLFUW (2006): Richtlinie zur Bewertung der Innenraumluft, erarbeitet vom Arbeitskreis Innenraumluft am Bundesministerium für Land-und Forstwirtschaft, Umwelt und Wasserwirtschaft und der Österreichischen Akademie der Wissenschaften, Blau-Weiße Reihe (Loseblattsammlung); Österreichische Akademie der Wissenschaften: Wien, Austria. Available online: https: //www.bmlrt.gv.at/umwelt/luft-laerm-verkehr/luft/innenraumluft/richtlinie_innenraum.html (accessed on 16 February 2020).

30. Ministério Das Obras Públicas, Transportes e Comunicações. Decreto-Lei n. 79/2006 de 4 de Abril. Diário da República, I Série-A n. 67; Ministério Das Obras Públicas, Transportes e Comunicações: Lisboa, Portugal, 2006.

31. Ministérios das Finanças e da Economia e do Emprego. Decreto n. 60/2013 de 5 de fevereiro de 2013. Diário da República, 2a Série n. 25; Ministérios das Finanças e da Economia e do Emprego: Lisboa, Portugal, 2013.

32. World Health Organization. Air quality guidelines for Europe, 2nd ed.; WHO Regional Publications: Copenhagen, Denmark, 2000.

33. World Health Organization. Air quality guidelines. Global Update 2005; WHO Regional Publications: Copenhagen, Denmark, 2006.

34. World Health Organization. Guidelines for indoor air quality: Selected pollutants. Copenhagen: WHO Regional Office for Europe. 2010. Available online: http://www.euro.who.int/_data/assets/pdf_file/0009/128 169/e94535.pdf (accessed on 18 January 2020). 
35. Norway Ministry of Labour and Social Affairs. Regulations concerning the design and layout of workplaces and work premises (the Workplace Regulations). FOR-2017-04-18-473. January 2013. Available online: https://lovdata.no/dokument/SFE/forskrift/2011-12-06-1356 (accessed on 5 February 2020).

36. Lietuvos Respublikos Sveikatos Apsaugos Ministras. Isakymas dèl Lietuvos Higienos Normos Hn 35:2007 “Didžiausia Leidžiama Cheminiu Medžiagu (Teršalu) Koncentracija Gyvenamosios Aplinkos Ore" Patvirtinimo. 10 May 2007, nr. V-362; Lietuvos Respublikos Sveikatos Apsaugos Ministras: Vilnius, Lithuania, 2007.

37. Ordinance of the Polish Minister of Labour and Social Policy of September 26, 1997 on General Safety and Health. J. Laws 2003, 169, 1650.

38. Fuselli, S.; Pilozzi, A.; Santarsiero, A.; Settimo, G.; Brini, S.; Lepore, A.; de Gennaro, G.; Loiotile, A.D.; Marzocca, A.; de Martino, A.; et al. Monitoring strategies for volatile organic compounds (VOCs) in indoor environments. Rapp. ISTISAN 2013, 13/04,31. Available online: http://old.iss.it/binary/publ/cont/13_4_web.p df (accessed on 1 March 2020).

39. Bonadonna, L.; Briancesco, R.; Brunetto, B.; Coccia, A.M.; De Gironimo, V.; Della Libera, S.; Fuselli, S.; Gucci, P.M.B.; Iacovacci, P.; Lacchetti, I.; et al. Monitoring strategies of biological air pollution in indoor environment. Rapp. ISTISAN 2013, 13/37, 72. Available online: http://old.iss.it/binary/publ/cont/13_37_web. pdf (accessed on 1 March 2020).

40. Fuselli, S.; Musmeci, L.; Pilozzi, A.; Santarsiero, A.; Settimo, G. Proceedings on Indoor air pollution: Current situation in Italy. Rome, 25 June 2012. Rapp. ISTISAN 2013, 13/39, 85. Available online: http: //old.iss.it/binary/publ/cont/13_39_web.pdf (accessed on 1 March 2020).

41. Santarsiero, A.; Musmeci, L.; Fuselli, S. Proceedings on Indoor air quality: Current national and European situation. The expertise of the National Working Group on indoor air. Rome, 28 May 2014. Rapp. ISTISAN 2015, 15/04, 134. Available online: http://old.iss.it/binary/publ/cont/15_4_web.pdf (accessed on 1 March 2020).

42. Musmeci, L.; Fuselli, S.; Bruni, B.M.; Sala, O.; Bacci, T.; Somigliana, A.B.; Campopiano, A.; Prandi, S.; Garofani, P.; Martinelli, C.; et al. Monitoring strategies to assess the concentration of airborne asbestos and man-made vitreous fibres in the indoor environment. Rapp. ISTISAN 2015, 15/05, 37. Available online: http://old.iss.it/binary/publ/cont/15_5_web.pdf (accessed on 1 March 2020).

43. Santarsiero, A.; Musmeci, L.; Ricci, A.; Corasaniti, S.; Coppa, P.; Bovesecchi, G.; Merluzzi, R.; Fuselli, S. Microclimate parameters and indoor air pollution. Rapp. ISTISAN 2015, 15/25, 62. Available online: http://old.iss.it/binary/publ/cont/15_25_web.pdf (accessed on 1 March 2020).

44. Settimo, G.; Baldassarri, L.T.; Brini, S.; Lepore, A.; Moricci, F.; de Martino, A.; Casto, L.; Musmeci, L.; Nania, M.A.; Costamagna, F.; et al. Presence of $\mathrm{CO}_{2}$ and $\mathrm{H}_{2} \mathrm{~S}$ in indoor environments: Current knowledge and scientific field literature. Rapp. ISTISAN 2016, 16/15, 30. Available online: http://old.iss.it/binary/publ/c ont/16_15_web.pdf (accessed on 1 March 2020).

45. Settimo, G.; Musmeci, L.; Marzocca, A.; Cecinato, A.; Cattani, G.; Fuselli, S. Monitoring strategies to PM $_{10}$ and $\mathrm{PM}_{2.5}$ in indoor environments: Characterization of inorganic and organic micropollutants. Rapp. ISTISAN 2016, 16/16, 34. Available online: http://old.iss.it/binary/publ/cont/16_16_web.pdf (accessed on 1 March 2020).

46. Nuccetelli, C.; Risica, S.; Onisei, S.; Leonardi, F.; Trevisi, R. Natural radioactivity in building materials in the European Union: A database of activity concentrations, radon emanations and radon exhalation rates. Rapp. ISTISAN 2017, 17/36, 70. Available online: http://old.iss.it/binary/publ/cont/17_36_web.pdf (accessed on 1 March 2020).

47. Settimo, G.; Bonadonna, L.; Gherardi, M.; di Gregorio, F.; Cecinato, A. Indoor air quality in healthcare environments: Strategies for monitoring chemical and biological pollutants. Rapp. ISTISAN 2019, 19/17, 55. Available online: http://old.iss.it/binary/publ/cont/19_17_web.pdf (accessed on 1 March 2020).

48. Settimo, G.; Bonadonna, L.; Gucci, P.M.B.; Gherardi, M.; Cecinato, A.; Brini, S.; De Maio, F.; Lepore, A.; Giardi, G. Qualità dell'aria indoor negli ambienti scolastici: strategie di monitoraggio degli inquinanti chimici e biologici. Rapp. ISTISAN 2020, 20/3, 67.

49. Pierpaoli, M.; Ruello, M.L. Indoor Air Quality: A bibliometric study. Sustainability 2018, 10, 3830. [CrossRef]

50. Manigrasso, M.; Vitali, M.; Protano, C.; Avino, P. Ultrafine particles in domestic environments: Regional doses deposited in the human respiratory system. Environ. Int. 2018, 118, 134-145. [CrossRef]

51. Romagnoli, P.; Balducci, C.; Perilli, M.; Vichi, F.; Imperiali, A.; Cecinato, A. Indoor air quality at life and work environments in Rome, Italy. Environ. Sci. Pollut. Res. 2016, 23, 3503-3516. [CrossRef] 
52. Di Gilio, A.; Farella, G.; Marzocca, A.; Giua, R.; Assennato, G.; Tutino, M.; De Gennaro, G. Indoor/outdoor air quality assessment at school near the steel plant in Taranto (Italy). Adv. Meteorol. 2017, 2017, 1526209. [CrossRef]

53. Stabile, L.; Massimo, A.; Canale, L.; Russi, A.; Andrade, A.; Dell'Isola, M. The effect of ventilation strategies on indoor air quality and energy consumptions in classrooms. Buildings 2019, 9, 110. [CrossRef]

54. Stabile, L.; Buonanno, G.; Frattolillo, A.; Dell'Isola, M. The effect of the ventilation retrofit in a school on $\mathrm{CO}_{2}$, airborne particles, and energy consumptions. Build. Environ. 2019, 156,1-11. [CrossRef]

55. Aversa, P.; Settimo, G.; Gorgoglione, M.; Bucci, E.; Padula, G.; de Marco, A. A case study of indoor air quality in a classroom by comparing passive and continuous monitoring. Environ. Eng. Manag. J. 2019, 18, 2107-2115.

56. Schibuola, L.; Tambani, C. Indoor environmental quality classification of school environments by monitoring $\mathrm{PM}$ and $\mathrm{CO}_{2}$ concentration levels. Atmos. Pollut. Res. 2020, 11, 332-342. [CrossRef]

57. Azara, A.; Dettori, M.; Castiglia, P.; Piana, A.; Durando, P.; Parodi, V.; Salis, G.; Saderi, L.; Sotgiu, G. Indoor radon exposure in Italian schools. Int. J. Environ. Res. Pub. Health 2018, 15, 749. [CrossRef] [PubMed]

58. Di Carlo, C.; Lepore, L.; Gugliermetti, L.; Remetti, R. An inexpensive and continuous radon progeny detector for indoor air-quality monitoring. In WIT Transactions on Ecology and the Environment; Passerini, G., Borrego, C., Longhurst, J., Lopes, M., Barnes, J., Eds.; WIT Press: Ashurst, UK, 2019; Volume 236, pp. 325-333.

59. De Gennaro, G.; Dambruoso, P.R.; Di Gilio, A.; di Palma, V.; Marzocca, A.; Tutino, M. Discontinuous and continuous indoor air quality monitoring in homes with fireplaces or wood stoves as heating system. Int. J. Environ. Res. Pub. Health 2015, 13, 78. [CrossRef]

60. Stabile, L.; Buonanno, G.; Avino, P.; Frattolillo, A.; Guerriero, E. Indoor exposure to particles emitted by biomass-burning heating systems and evaluation of dose and lung cancer risk received by population. Environ. Pollut. 2018, 235, 65-73. [CrossRef]

61. Marchetti, S.; Longhin, E.; Bengalli, R.; Avino, P.; Stabile, L.; Buonanno, G.; Colombo, A.; Camatini, M.; Mantecca, P. In vitro lung toxicity of indoor $\mathrm{PM}_{10}$ from a stove fueled with different biomasses. Sci. Total Environ. 2019, 649, 1422-1433. [CrossRef]

62. Gola, M.; Settimo, G.; Capolongo, S. Chemical pollution in healing spaces: The decalogue of the best practices for adequate indoor air quality in inpatient rooms. Int. J. Environ. Res. Pub. Health 2019, 16, 4388. [CrossRef]

63. Gola, M.; Settimo, G.; Capolongo, S. Indoor air in healing environments: Monitoring chemical pollution in inpatient rooms. Facilities 2019, 37, 600-623. [CrossRef]

64. Manigrasso, M.; Guerriero, E.; Avino, P. Ultrafine particles in residential indoors and doses deposited in the human respiratory system. Atmosphere 2015, 6, 1444-1461. [CrossRef]

65. Manigrasso, M.; Vitali, M.; Protano, C.; Avino, P. Temporal evolution of ultrafine particles and of alveolar deposited surface area from main indoor combustion and non-combustion sources in a model room. Sci. Total Environ. 2017, 598, 1015-1026. [CrossRef]

66. Avino, P.; Scungio, M.; Stabile, L.; Cortellessa, G.; Buonanno, G.; Manigrasso, M. Second-hand aerosol from tobacco and electronic cigarettes: Evaluation of the smoker emission rates and doses and lung cancer risk of passive smokers and vapers. Sci. Total Environ. 2018, 642, 137-147. [CrossRef] [PubMed]

67. Zanni, S.; Lalli, F.; Foschi, E.; Bonoli, A.; Mantecchini, L. Indoor air quality real-time monitoring in airport terminal areas: An opportunity for sustainable management of micro-climatic parameters. Sensors 2018, 18, 3798. [CrossRef] [PubMed]

68. Siani, A.M.; Frasca, F.; Di Michele, M.; Bonacquisti, V.; Fazio, E. Cluster analysis of microclimate data to optimize the number of sensors for the assessment of indoor environment within museums. Environ. Sci. Pollut. Res. 2018, 25, 28787-28797. [CrossRef] [PubMed]

69. Cincinelli, A.; Martellini, T.; Amore, A.; Dei, L.; Marrazza, G.; Carretti, E.; Belosi, F.; Ravegnani, F.; Leva, P. Measurement of volatile organic compounds (VOCs) in libraries and archives in Florence (Italy). Sci. Total Environ. 2016, 572, 333-339. [CrossRef] 
70. Tirler, W.; Settimo, G. Incense, sparklers and cigarettes are significant contributors to indoor benzene and particle levels. Ann. I. Super. Sanita 2015, 51, 28-33.

71. SWD. Commission Staff Working Document, 143, Accompanying the Document, Report form the Commission to the European Parliament and the Council, Financial Support for Energy Efficiency in Buildings. 2013. Available online: https://ec.europa.eu/energy/sites/ener/files/documents/swd_2013_143_accomp_report_fin ancing_ee_buildings.pdf (accessed on 18 April 2013). 